almost only AxSpA patients fulfilled the requirements. BME adjacent to sclerosis was most frequent in women with postpartum pain, whereas BME adjacent to ankylosis was only seen in patients with axSpA. Conclusion: BME located adjacent to joint space, adjacent to erosion and adjacent to fat was most frequently, but not exclusively, occurring in patients with axSpA, whilst BME adjacent to sclerosis was most frequent in women with postpartum pain. Detailed analysis of lesions and their anatomical location may help differentiate axSpA from other conditions.

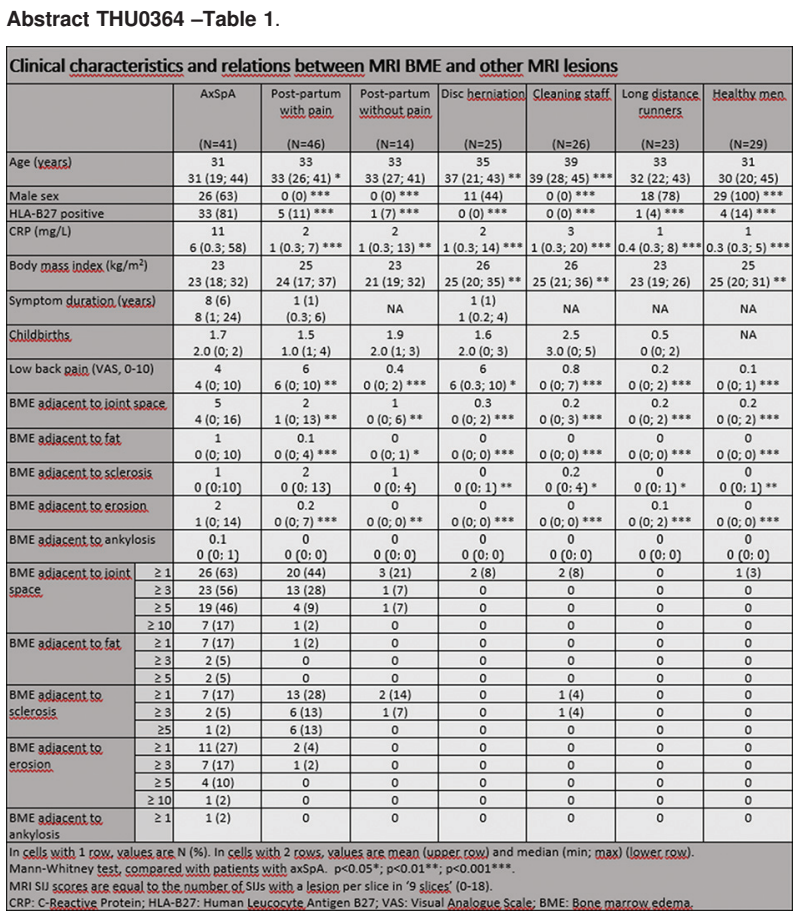

REFERENCES:

[1] Rudwaleit, et al. Ann Rheum 2009.

[2] Lambert, et al. Ann Rheum 2016.

[3] Weber, et al. Arthritis Rheum 2010.

[4] Varkas, et al. Rheumatology (Oxford) 2018.

[5] de Winter, et al. Arthritis Rheumatol 2018.

[6] Arnbak, et al. Eur Radiol 2016.

[7] Seven, et al. Ann Rheum 2018.

[8] Maksymowych, et al. Arthritis Rheum 2005.

[9] Maksymowych, et al. J Rheumatol 2015.

Disclosure of Interests: Sengül Seven: None declared, Pernille Hededal: None declared, Mikkel Ǿstergaard Grant/research support from: Abbvie, Celgene, Centocor, Merck, Novartis, Consultant for: Abbvie, BMS, Boehringer-Ingelheim, Celgene, Eli Lilly, Hospira, Janssen, Merck, Novartis, Novo, Orion, Pfizer, Regeneron, Roche, and UCB, Speakers bureau: Abbvie, BMS, Boehringer-Ingelheim, Celgene, Eli Lilly, Hospira, Janssen, Merck, Novartis, Novo, Orion, Pfizer, Regeneron, Roche, and UCB, Lone Morsel-Carlsen: None declared, Inge Juul Sørensen: None declared, Birthe Bonde: None declared, Gorm Thamsborg: None declared, Jens Jørgen Lykkegaard: None declared, Oliver Hendricks Grant/research support from: AbbVie, Novartis, Niklas Rye Jørgensen: None declared, Susanne Juhl Pedersen: None declared

DOI: 10.1136/annrheumdis-2019-eular.3227

\section{THU0365 THE IMPACT OF UVEITIS, PSORIASIS AND INFLAMMATORY BOWEL DISEASE ON MUSCULOSKELETAL DISEASE ACTIVITY AND FUNCTION IN AXIAL SPONDYLOARTHRITIS: A POPULATION-BASED ANALYSIS OF INSURANCE CLAIMS LINKED TO PATIENT SURVEY DATA}

Imke Redeker ${ }^{1}$, Johanna Callhoff ${ }^{2}$, Falk Hoffmann ${ }^{3}$, Hildrun Haibel ${ }^{1}$, Joachim Sieper ${ }^{1}$, Angela Zink ${ }^{2}$, Denis Poddubnyy ${ }^{1} .{ }^{1}$ Charité - Universitätsmedizin Berlin, Department of Gastroenterology, Infectiology and Rheumatology, Berlin, Germany, ${ }^{2}$ German Rheumatism Research Centre, Epidemiology Unit, Berlin, Germany, ${ }^{3}$ Carl von Ossietzky University, Department of Health Services Research, Oldenburg, Germany

Background: Uveitis, psoriasis and inflammatory bowel disease (IBD) are common in axial spondyloarthritis (axSpA) but data on their impact on activity of musculoskeletal manifestations and functional status in general are contradictory.

Objectives: The aim of this study was to assess the impact of uveitis, psoriasis and IBD on disease activity and functional status in a population-based cohort of patients with axSpA.

Methods: A stratified random sample of subjects with a diagnosis of axSpA (ICD-10 M45) was drawn from health insurance data in Germany. These patients received a questionnaire on disease-related, demographic and socioeconomic parameters. Age, sex, drug prescriptions and nonpharmacological treatment were retrieved from claims data and linked to the questionnaire data. Information on recent/current occurrence of uveitis, psoriasis and IBD (within one year) was obtained from claims data; in addition, information on history of uveitis, psoriasis and IBD was obtained from survey data. Patients with uveitis, psoriasis or IBD were compared to those without uveitis, psoriasis or IBD. Separate multivariable linear regression models were calculated to determine the effect of uveitis, psoriasis and IBD on disease activity and functional status after adjustment for other relevant parameters including treatment.

Abstract THU0365 -Table 1

Table Results from multivariable linear regression models showing the association of psoriasis, inflammatory bowe disease and uveitis with disease activity (BASDAI) and functional impairment (BASFI) in patients with axial disease and uveitis with dilsed

\begin{tabular}{|c|c|c|c|c|}
\hline \multicolumn{5}{|c|}{ Recent psoriasis, inflammatory bowel disease, and uveitis (based on claims data) } \\
\hline & & Reference & $\begin{array}{l}\text { BASDAI* } \\
\beta(95 \% \mathrm{Cl})\end{array}$ & $\begin{array}{l}\text { BASFF** } \\
\beta(95 \% \mathrm{Cl})\end{array}$ \\
\hline Model 1a & Psoriasis, recently present & not present & $0.07(-0.27,0.40)$ & $0.30(-0.09,0.70)$ \\
\hline Model $1 \mathrm{~b}$ & $\begin{array}{l}\text { Inflammatory bowel disease, } \\
\text { recently present }\end{array}$ & not present & $0.30(-0.10,0.71)$ & $0.33(-0.14,0.80)$ \\
\hline Model $1 \mathrm{c}$ & Uveitis, recently present & not present & $-0.44(-0.77,-0.10)$ & $-0.38(-0.77,0.02)$ \\
\hline \multicolumn{5}{|c|}{ History of psoriasis, inflammatory bowel disease, and uveitis (based on survey data) } \\
\hline & & Reference & $\begin{array}{l}\text { BASDAI* } \\
\beta(95 \% \mathrm{Cl})\end{array}$ & $\begin{array}{l}\text { BASFF** } \\
\beta(95 \% \mathrm{Cl})\end{array}$ \\
\hline Model 2a & Psoriasis, ever present & not present & $0.31(0.05,0.58)$ & $0.37(0.05,0.68)$ \\
\hline Model 2b & $\begin{array}{l}\text { Inflammatory bowel disease, } \\
\text { ever present }\end{array}$ & not present & $0.37(0.01,0.73)$ & $0.35(-0.07,0.77)$ \\
\hline Model 2c & Uveitis, ever present & not present & $-0.10(-0.31,0.11)$ & $-0.01(-0.26,0.24)$ \\
\hline
\end{tabular}

Results: A total of 1,729 patients with axSpA were included in the analyses; mean age was 55.9 years and $46.1 \%$ were female. The prevalence was $9 \%(27 \%)$ for recent (ever) uveitis, 10\% (15\%) for recent (ever) psoriasis, and $6 \%(9 \%)$ for recent (ever) IBD. In $1.6 \%(6.9 \%)$ of the patients two of these conditions were recently (ever) present, and in $0 \%$ $(0.5 \%)$ of the patients, all three conditions were recently (ever) present. The multivariable linear regression analyses revealed that history of psoriasis was significantly associated with both higher level of disease activity and higher level of functional impairment. History of IBD was also associated with higher disease activity, whereas recent psoriasis or IBD showed no strong association with disease activity and functional status (Table). In contrast, history of uveitis showed no strong association with disease activity and functional status while recent uveitis was significantly associated with lower disease activity according to the BASDAI even after adjustment for treatment.

Conclusion: Disease activity and functional impairment are higher in axSpA patients with a history of psoriasis or IBD, whereas history of 
uveitis does not have a major impact on activity of musculoskeletal manifestations and functional status in axSpA. However, recent uveitis showed a somewhat unexpected association with lower disease activity. The latter might be related to a higher likelihood of being treated with TNF inhibitors in the presence of uveitis

Acknowledgement: This work was supported by the Federal Ministry of Education and Research within the research network PROCLAIR (01EC1405).

Disclosure of Interests: Imke Redeker: None declared, Johanna Callhoff: None declared, Falk Hoffmann: None declared, Hildrun Haibel: None declared, Joachim Sieper Consultant for: Abbvie, Böhringer Ingelheim, Janssen, Lilly, Merck, Mylan, Novartis, Pfizer, UCB., Speakers bureau: Abbvie, Böhringer Ingelheim, Janssen, Lilly, Merck, Mylan, Novartis, Pfizer, UCB., Angela Zink Speakers bureau: Speakers fees from AbbVie, Janssen, Pfizer, Roche, Sanofi, Denis Poddubnyy Grant/research support from: AbbVie, Merck Sharp \& Dohme, Novartis, Consultant for: AbbVie, BristolMyers Squibb, Janssen, Merck Sharp \& Dohme, Novartis, Pfizer, UCB Pharma, Speakers bureau: AbbVie, Bristol-Myers Squibb, Janssen, Merck Sharp \& Dohme, Novartis, Pfizer, Roche, UCB Pharma DOI: 10.1136/annrheumdis-2019-eular.5328

\section{THU0366 MAGNETIC RESONANCE IMAGING IN COMPARISON WITH CONVENTIONAL RADIOGRAPHY FOR DETECTION OF STRUCTURAL CHANGES TYPICAL FOR SPA - DATA FROM THE ASSESSMENT OF SPONDYLOARTHRITIS INTERNATIONAL SOCIETY (ASAS) COHORT}

Mikhail Protopopov ${ }^{1}$, Denis Poddubnyy ${ }^{1,2}$, Fabian Proft ${ }^{1}$, Stephanie Wichuk ${ }^{3}$, Pedro Machado $^{4}$, Robert G Lambert ${ }^{5}$, Ulrich Weber ${ }^{6,7}$, Susanne Juhl Pedersen ${ }^{8,9}$, Mikkel Ǿstergaard ${ }^{8,9}$, Joachim Sieper $^{1}$, Martin Rudwaleit ${ }^{10}$, Xenofon Baraliakos $^{11}$ Walter P Maksymowych ${ }^{3} .{ }^{1}$ Charité Universitätsmedizin Berlin, Department of Gastroenterology, Infectiology and Rheumatology, Campus Benjamin Franklin, Berlin, Germany, ${ }^{2}$ German Rheumatism Research Centre, Berlin, Germany; ${ }^{3}$ University of Alberta, Department of Medicine, Edmonton, Canada; ${ }^{4}$ University College London, Centre for Rheumatology and MRC Centre for Neuromuscular Diseases, London, United Kingdom; ${ }^{5}$ University of Alberta, Department of Radiology and Diagnostic Imaging, Edmonton, Canada; ${ }^{6}$ King Christian 10th Hospital for Rheumatic Diseases, Gråsten, Denmark; ${ }^{7}$ University of Southern Denmark, Institute of Regional Health Research, Odense, Denmark; ${ }^{8}$ Copenhagen Center for Arthritis Research, Center for Rheumatology and Spine Diseases, Rigshospitalet, Copenhagen, Denmark; ${ }^{9}$ University of Copenhagen, Department of Clinical Medicine, Faculty of Health and Medical Sciences, Copenhagen, Denmark; ${ }^{10}$ Klinikum Bielefeld Rosenhöhe, Bielefeld, Germany; ${ }^{11}$ Ruhr-University Bochum, Rheumazentrum Ruhrgebiet, Herne, Germany

Background: In axial spondyloarthritis, magnetic resonance imaging (MRI) is useful for depicting active inflammatory lesions. The utility of MRI to display structural changes is not that well established.

Objectives: Comparison of MRI and conventional radiography of the sacroiliac joints (SIJs) for detection of structural lesions typical for axial spondyloarthritis (axSpA) in an international multireader exercise.

Methods: Patients from the ASAS Cohort with symptoms suggestive of axSpA and both radiographs and T1-weighted MRIs of SIJs available for central reading were included. SIJs radiographs were scored by 3 central readers according to the modified New York (mNY) criteria grading system. Structural damage on radiographs was defined as fulfillment of the radiographic $\mathrm{mNY}$ criterion (patient level) or presence of grade 2 sacroiliitis (single joint level) (majority decision). MRI scans were assessed for structural changes compatible with axSpA (global statement) and separate changes (erosion, sclerosis, periarticular fat metaplasia and ankylosis) by 7 central readers (majority decision). Absolute agreement between MRI and radiography and Kappa coefficient were determined.

Results: Overall, 199 patients (398 joints) were included, 149 (74.9\%) had a diagnosis of axSpA. $102(51.3 \%)$ had definite radiographic sacroiliitis, $65(32.7 \%)$ had structural changes suggestive of SpA on MRI (global assessment). The absolute agreement between $\mathrm{MRI}$ and radiography was $69.3 \%$, kappa - 0.39 (Table 1). Structural damage on radiographs often (48.1\% of cases) could not be confirmed by MRI. Among structural lesions, erosions on MRI showed the best discriminative capacity regarding the structural damage on radiographs (Table 1).

Conclusion: Only modest agreement between $\mathrm{MRI}$ and conventional radiography in detection of structural changes typical for SpA in the SIJs was revealed; erosions on MRI showed the best agreement with the presence of definite structural damage on radiographs.
Abstract THU0366 -Table 1.

Table 1. Comparison of MRI with conventional radiographs for the detection of structural damage in the sacroiliac joints at the patient level ( $n=199)$

\begin{tabular}{|c|c|c|c|c|c|}
\hline & \multicolumn{2}{|c|}{$\begin{array}{l}\text { Radiographic sacroilititis } \\
\text { fulfilling the mNY criteria }\end{array}$} & \multirow{2}{*}{$\begin{array}{l}\text { Absolute } \\
\text { agreement }\end{array}$} & \multirow{2}{*}{$\begin{array}{l}\text { Kappa } \\
\text { value }\end{array}$} \\
\hline & & $\begin{array}{c}\text { No } \\
(n=97)\end{array}$ & $\begin{array}{c}\text { Yes } \\
(n=102)\end{array}$ & & \\
\hline \multirow{2}{*}{$\begin{array}{l}\text { Presence of } \\
\text { structural lesions } \\
\text { typical for SpA on } \\
\text { MRI according to the } \\
\text { global assessment }\end{array}$} & No $(n=134)$ & $85(42.7 \%)$ & $49(24.6 \%)$ & \multirow{2}{*}{$69.3 \%$} & \multirow{2}{*}{$\mathrm{k}=0.39$} \\
\hline & Yes $(n=65)$ & $12(6.0 \%)$ & $53(26.6 \%)$ & & \\
\hline \multirow{2}{*}{$\begin{array}{l}\text { Presence of any } \\
\text { structural changes } \\
\text { (erosions, sclerosis, } \\
\text { ankylosis or fat } \\
\text { metaplasia) on MRI }\end{array}$} & No $(n=120)$ & 77 (38.7\%) & $43(21.6 \%)$ & \multirow{2}{*}{$69.3 \%$} & \multirow{2}{*}{$k=0.37$} \\
\hline & Yes $(n=79)$ & $20(10.1 \%)$ & $59(29.6 \%)$ & & \\
\hline \multirow{2}{*}{$\begin{array}{l}\text { Presence of erosions } \\
\text { or sclerosis or } \\
\text { ankylosis on MRI }\end{array}$} & No $(n=124)$ & 79 (39.7\%) & $45(22.6 \%)$ & \multirow{2}{*}{$68.3 \%$} & \multirow{2}{*}{$k=0.37$} \\
\hline & Yes $(n=75)$ & $18(9.0 \%)$ & $57(28.6 \%)$ & & \\
\hline \multirow{2}{*}{$\begin{array}{l}\text { Presence of erosions } \\
\text { on MRI }\end{array}$} & No $(n=141)$ & $85(42.7 \%)$ & $56(28.1 \%)$ & \multirow{2}{*}{$65.8 \%$} & \multirow{2}{*}{$k=0.32$} \\
\hline & Yes $(n=58)$ & $12(6.0 \%)$ & 46 (24.1\%) & & \\
\hline \multirow{2}{*}{$\begin{array}{l}\text { Presence of sclerosis } \\
\text { on MRI }\end{array}$} & No $(n=163)$ & $90(45.2 \%)$ & $73(36.7 \%)$ & \multirow{2}{*}{$59.8 \%$} & \multirow{2}{*}{$\kappa=0.21$} \\
\hline & Yes $(n=36)$ & $7(3.5 \%)$ & $29(14.6 \%)$ & & \\
\hline \multirow{2}{*}{$\begin{array}{l}\text { Presence of ankylosis } \\
\text { on MRI }\end{array}$} & No $(n=195)$ & $97(48.7 \%)$ & $98(49.2 \%)$ & \multirow{2}{*}{$50.8 \%$} & \multirow{2}{*}{$\mathrm{K}=0.04$} \\
\hline & Yes $(n=4)$ & $0(0.0 \%)$ & $4(2.0 \%)$ & & \\
\hline \multirow{2}{*}{$\begin{array}{l}\text { Presence of fat } \\
\text { metaplasia on MRI }\end{array}$} & No $(n=157)$ & $90(45.2 \%)$ & $67(33.7 \%)$ & \multirow{2}{*}{$62.8 \%$} & \multirow{2}{*}{$\mathrm{k}=0.27$} \\
\hline & Yes $(n=42)$ & $7(3.5 \%)$ & $35(17.6 \%)$ & & \\
\hline
\end{tabular}

magnetic resonance imoging

Abstract THU0366 -Table 2.

Table 2. Comparison of MRI with conventional radiographs for the detection of structural damage in the sacroiliac joints at the single joint level ( $n=398)$

\begin{tabular}{|c|c|c|c|c|c|}
\hline & \multicolumn{2}{|c|}{$\begin{array}{l}\text { Definite radiographic sacroiliitis } \\
\qquad \text { (grade }>=2 \text { ) }\end{array}$} & \multirow[t]{2}{*}{$\begin{array}{c}\text { Absolute } \\
\text { agreement }\end{array}$} & \multirow[t]{2}{*}{$\begin{array}{l}\text { Kappa } \\
\text { value }\end{array}$} \\
\hline & & $\begin{array}{c}\text { No } \\
(n=209)\end{array}$ & $\begin{array}{c}\text { Yes } \\
(n=199)\end{array}$ & & \\
\hline \multirow{2}{*}{\begin{tabular}{|l|} 
Presence of any \\
structural changes \\
(erosions, sclerosis, \\
ankylosis or fat \\
metaplasia) on MRI \\
\end{tabular}} & No $(n=272)$ & $184(46.2 \%)$ & $88(22.1 \%)$ & \multirow{2}{*}{$71.6 \%$} & \multirow{2}{*}{$k=0.42$} \\
\hline & Yes $(n=126)$ & $25(6.3 \%)$ & $101(25.4 \%)$ & & \\
\hline \multirow{2}{*}{$\begin{array}{l}\text { Presence of erosions } \\
\text { or sclerosis or } \\
\text { ankylosis on MRI }\end{array}$} & No $(n=283)$ & $187(47.0 \%)$ & $96(24.1 \%)$ & \multirow{2}{*}{$70.4 \%$} & \multirow{2}{*}{$\mathrm{k}=0.39$} \\
\hline & Yes $(n=115)$ & $22(5.5 \%)$ & $93(23.4 \%)$ & & \\
\hline \multirow{2}{*}{$\begin{array}{l}\text { Presence of erosions } \\
\text { on MRI }\end{array}$} & No $(n=312)$ & $192(48.2 \%)$ & $120(30.2 \%)$ & \multirow{2}{*}{$65.6 \%$} & \multirow{2}{*}{$k=0.29$} \\
\hline & Yes $(n=86)$ & $17(4.3 \%)$ & $69(17.3 \%)$ & & \\
\hline \multirow{2}{*}{$\begin{array}{l}\text { Presence of sclerosis } \\
\text { on MRI }\end{array}$} & No $(n=345)$ & $201(50.5 \%)$ & $144(36.2 \%)$ & \multirow{2}{*}{$61.8 \%$} & \multirow{2}{*}{$k=0.21$} \\
\hline & Yes $(n=53)$ & $8(2.0 \%)$ & 45 (11.3\%) & & \\
\hline \multirow{2}{*}{$\begin{array}{l}\text { Presence of ankylosis } \\
\text { on MRI }\end{array}$} & No $(n=393)$ & 209 (52.5\%) & $184(46.2 \%)$ & \multirow{2}{*}{$53.8 \%$} & \multirow{2}{*}{$\mathrm{k}=0.03$} \\
\hline & Yes $(n=5)$ & $0(0.0 \%)$ & $5(1.3 \%)$ & & \\
\hline \multirow{2}{*}{$\begin{array}{l}\text { Presence of fat } \\
\text { metaplasia on MRI }\end{array}$} & No $(n=330)$ & 195 (49.0\%) & $135(33.9 \%)$ & \multirow{2}{*}{$62.6 \%$} & \multirow{2}{*}{$\mathrm{k}=0.23$} \\
\hline & Yes $(n=68)$ & $14(3.5 \%)$ & $54(13.6 \%)$ & & \\
\hline
\end{tabular}

Disclosure of Interests: Mikhail Protopopov: None declared, Denis Poddubnyy Grant/research support from: AbbVie, Merck Sharp \& Dohme, Novartis, Consultant for: AbbVie, Bristol-Myers Squibb, Janssen, Merck Sharp \& Dohme, Novartis, Pfizer, UCB Pharma, Speakers bureau: AbbVie, Bristol-Myers Squibb, Janssen, Merck Sharp \& Dohme, Novartis, Pfizer, Roche, UCB Pharma, Fabian Proft Grant/research support from: Novartis, Consultant for: yes but less than 10.000, Paid instructor for: yes but less than 10.000, Speakers bureau: yes but less than 10.000 Stephanie Wichuk: None declared, Pedro Machado Consultant for: Abbvie, BMS, Celgene, Janssen, MSD, Novartis, Pfizer, Roche and UCB, 